\title{
Construction of yellow fever virus subgenomic replicons by yeast-based homologous recombination cloning technique
}

\author{
SABRINA R.A. QUEIROZ ${ }^{*}$, ANDRÉA N.M.R. SILVA ${ }^{1 *}$, JEFFERSON J.S. SANTOS $^{1 *}$, \\ ERNESTO T.A. MARQUES Jr ${ }^{1}$, GIOVANI R. BERTANI ${ }^{2}$ and LAURA H.V.G. GIL ${ }^{1}$ \\ ${ }^{1}$ Departamento de Virologia e Terapia Experimental, Centro de Pesquisas Aggeu Magalhães, \\ Fundação Oswaldo Cruz, Av. Professor Moraes Rego, s/n, Cidade Universitária, \\ Campus da Universidade Federal de Pernambuco, 50760-420 Recife, PE, Brasil \\ ${ }^{2}$ Departamento de Bioquímica, Universidade Federal de Pernambuco, Av. Professor Moraes Rego, s/n, \\ Cidade Universitária, Campus da Universidade Federal de Pernambuco, 50760-420, Recife, PE, Brasil
}

Manuscript received on May 5, 2011; accepted for publication on September 13, 2011

\begin{abstract}
RNA replicon derived from Flavivirus genome is a valuable tool for studying viral replication independent of virion assembly and maturation, besides being a great potencial for heterologous gene expression. In this study we described the construction of subgenomic replicons of yellow fever virus by yeast-based homologous recombination technique. The plasmid containing the yellow fever 17D strain replicon (pBSCrepYFV-17D), previously characterized, was handled to heterologous expression of the green fluorescent protein (repYFV-17D-GFP) and firefly luciferase (repYFV-17D-Luc) reporter genes. Both replicons were constructed by homologous recombination between the linearized vector pBSC-repYFV-17D and the PCR product containing homologous 25 nucleotides ends incorporated into PCR primers. The genomic organization of these constructs is similar to repYFV-17D, but with insertion of the reporter gene between the remaining $63 \mathrm{~N}$-terminal nucleotides of the capsid protein and $72 \mathrm{C}$-terminal nucleotides of the $\mathrm{E}$ protein. The replicons repYFV-17D-GFP and repYFV-17D-Luc showed efficient replication and expression of the reporter genes. The yeast-based homologous recombination technique used in this study proved to be applicable for manipulation of the yellow fever virus genome in order to construct subgenomic replicons.
\end{abstract}

Key words: cloning technique, homologous recombination, replicon, reporter gene, yellow fever virus.

\section{INTRODUCTION}

The yellow fever virus (YFV) is a mosquitoborne agent transmitted mainly by species of the genera Aedes and Haemagogus that belongs to the Flavivirus genus of the Flaviviridae family. The YFV is the prototype Flavivirus, a genus of enveloped, single stranded, positive-sense RNA

*These authors contributed equally to this work Correspondence to: Laura Helena Vega Gonzales Gil E-mail:1gilfiocruz@gmail.com virus that is transmitted via arthropod vectors and include important human and veterinary pathogens as dengue virus, Japanese encephalitis and tick borne encephalitis virus (TBEV). The virus is endemic in tropical South America and sub-Saharan Africa and remains a serious threat to those countries. There is no antiviral therapy and vaccination with the attenuated YFV-17D strain has been the major strategy for yellow fever control (Gubler et al. 2007). 
The virus genome consists of a positivepolarity, single-stranded RNA of approximately $11 \mathrm{~Kb}$, encoding a single large polyprotein that is co- and post-translationally processed by viral and cell proteases to yield three structural proteins (C, prM and E) and seven non-structural (NS) proteins (NS1, NS2A, NS2B, NS3, NS4A, NS4B and NS5) from the $\mathrm{N}$-terminus to the $\mathrm{C}$-teminus, respectively (Jones et al. 2005, Kümmerer 2006).

Genetics analysis of positive-strand RNA viruses has been greatly facilitated by the use of recombinant DNA technology. In recent years it has been described the successful construction of full-length cDNA clones for several members of the flavivirus genus including YFV, dengue virus, West Nile virus and Kunjin virus (KUNV), among others (Bredenbeek et al. 2003, Imoto and Konish 2007, Khromykh and Westaway 1994, Polo et al. 1997, Puri et al. 2000, Sumiyoshi et al. 1992, Yamshchikov et al. 2005).

In order to extend a range of experimental tools in studies on flavivirus replication a selfreplicating RNA (subgenomic replicon) derived of KUNV, a close relative of West Nile virus, was constructed (Khromykh and Westaway 1997). Thereafter, replicons were described for several flaviviruses including DENV-2 (Ng et al. 2007), DENV-3 (Mosimann et al. 2010), YFV (Jones et al. 2005), WNV (Widman et al. 2008) and TBEV (Kofler et al. 2004).

Subgenomic replicons of positive-stranded RNA viruses contain all of genetic elements needed to amplify themselves in susceptible host cells, but lack some or all of the genes coding structural proteins (Jones et al. 2005). Replicons of flaviviruses have been constructed by the introduction of in-frame deletions removing the coding regions for proteins prM and $\mathrm{E}$ and in some cases also the majority of C protein (Gehrke et al. 2003). Consequently, these RNAs are replicated in cells, but are not packaged into viral particles. Replicons have proven to be valuable tool for studying replication independently of virion assembly and maturation (Khromykh and Westaway 1997). Moreover, they have great potencial as molecular tools for heterologous gene expression (Gehrke et al. 2003, Jones et al. 2005, Varnavski and Khromykh 1999).

Multiple strategies have been used for the construction of subgenomic replicons. However, these strategies seem to be cumbersome to perform because so many steps are required. The observation that linear DNA fragments can efficiently stimulate recombination in Saccharomyces cerevisiae has led to the rapid development of powerful methods for DNA manipulation in yeast (Oldenburg et al. 1997). One of these powerful methodologies is a yeastbased homologous recombination cloning technique (Shanks et al. 2009). This technique is based on the ability of yeast cells to recombine sequences similar during the natural event of homologous recombination that occurs to repair DNA damage during replication (Kuzminov 2001, Orr-Weaver et al. 1981). In this methodology, a DNA fragment containing homologous ends sequences with the vector can be directly cloned using in vivo recombination in the linearized vector (Gibson 2009). The advantages of yeast recombination are that multiple pieces of DNA can be sewn together seamlessly without multiple rounds of amplification, and without the need for ligation in vitro or the use of restriction sites. This method is efficient, robust and simple to perform (Gibson 2009, Shanks et al. 2009).

Although used to DNA manipulations in yeast (Gibson et al. 2008, Oldenburg et al. 1997, Panicali and Paoletti 1982, Post and Roizman, 1981) homologous recombination have been only occasionally used to genome manipulations of flavivirus (Pang et al. 2001, Polo et al. 1997, Puri et al. 2000).

In the the present report we use the homologous recombination in yeast to construct subgenomic replicons, derived from a full-length cDNA clone of 17D strain of YFV, that express biologically functional reporter genes green fluorescent protein (GFP) and firefly luciferase (Luc). 


\section{MATERIALS AND METHODS}

\section{Cell Culture}

BHK-21 cells were maintained at $37^{\circ} \mathrm{C}$ in minimum essential medium (MEM) supplemented with $1 \%$ antibiotics (penicillin $10.000 \mathrm{U} / \mathrm{mL}$ and streptomycin 10,.000 $\mu \mathrm{g} / \mathrm{mL}$, GIBCO) and $10 \%$ fetal bovine serum (FBS).

\section{YEAST AND E. COLI HOSTS}

The yeast Saccharomyces cerevisiae strain RFY206 (MATa, his3A200, leu2-3, lys2A201, ura3-52, trplA:hisG) was cultured with YPD broth (1\% Bacto-yeast, 2\% Bacto-peptone and 2\% dextrose), and selections were done using tryptophan (trp) dropout medium (Yeast Nitrogen Base without tryptophan). It was made competent by the lithium acetate procedure (Sambrook and Russell 2001). Electrocompetent E. coli strain DH10B (used for DNA propagation) were cultured using LuriaBertani medium.

\section{PlASMid CONSTRUCTS}

Homologous recombination in yeast was used for all plasmid constructions. The parental low copy number plasmid pBSC-repYFV-17D containing the prototype YFV-17D strain replicon (repYFV-17D) was previously characterized (Gil et al. unpublished data). The replicon repYFV-17D contains deletion of almost all of the structural proteins except 63 N-terminal nucleotides (nts) of the capsid protein and $72 \mathrm{C}$-terminal nts of the $\mathrm{E}$ protein. To facilite cloning of foreign genes, a unique cloning site NarI was incorporated between these sequences.

In this study, two similar YFV-17D replicons were constructed, both with the same overall genetic structure, but expressing the sequence that code for two different reporter genes: the green fluorescent protein (repYFV-17D-GFP) and the firefly luciferase (repYFV-17D-Luc). The generation of the repYFV-17D-GFP were based on homologous recombination between one PCR product and the linearized vector in yeast (Figure 1).

A

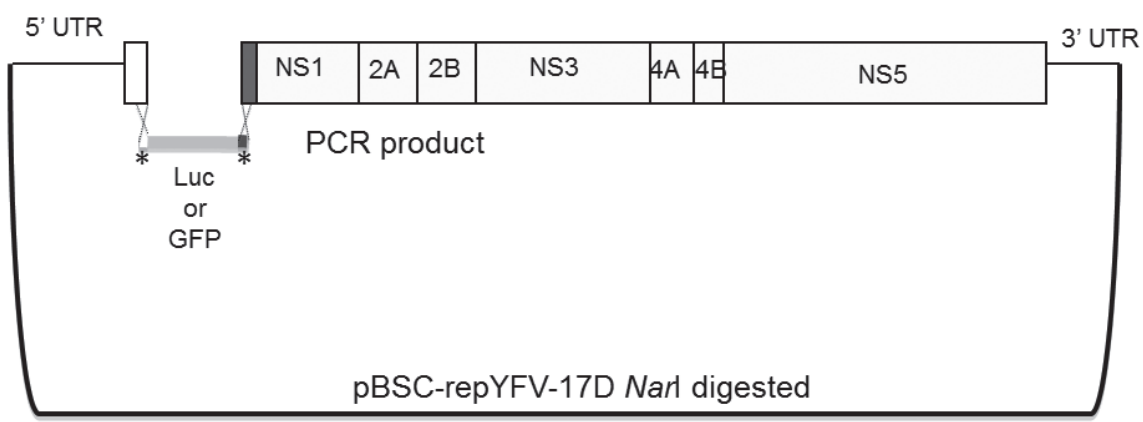

B

\begin{tabular}{l} 
rep-YFV-17D-GFP \\
rep-YFV-17D-Luc \\
\cline { 2 - 2 }
\end{tabular}

Figure 1- Schematic representation of construction of subgenomic replicons repYFV-17D-GFP and repYFV-17D-Luc. (A) Homologous recombination in yeast between a PCR product containing Luc or GFP gene and the vector pBSC-repYFV17D NarI digested. The PCR product is represented with a sequence identification. (B) Genome organization of subgenomic replicons repYFV-17D-GFP and repYFV-17D-Luc. * Homologous sequences (25 nts) for yeast recombination. 
The PCR fragment containing the GFP gene was amplified from the version of the plasmid Green Lantern (pGL) from Stratagene using one primer pair that contained homologous sequences for recombination with the NarI digested vector pBSC-repYFV-17D (Table I).
The PCR product and the linearized vector pBSC-repYFV-17D were used to transform competent RFY206. After transformation, yeast cells were plated out on solid trp dropout medium. Individual clones were screened by PCR to confirm the presence and correct orientation of

TABLE I

Primers used in the construction of subgenomic replicons YFV-17D.

\begin{tabular}{l|l}
\hline Primer $^{\mathrm{a}}$ & Sequence \\
\hline Rep-YFV-GFP-F $^{\mathrm{b}}$ & CAATATGGTACGACGAGGAGTTCGCATGAGCAAGGGCGAGGAACTGTTCAC \\
Rep-YFV-GFP-R & TCATGCTCATGGACATTGTCATGTTCTTGTACAGCTCGTCCATGCCATGTG \\
Rep-YFV-Luc-F & CAATATGGTACGACGAGGAGTTCGCATGGAAGACGCCAAAAACATAAAG \\
Rep-YFV-Luc-R & TCATGCTCATGGACATTGTCATGTTCAATTTGGACTTTCCGCCCTTCTTG \\
\hline
\end{tabular}

The homologous sequences for recombination in yeast are underlined.

${ }^{a}$ The primers are identified according to the sequences that have and / or amplify. ${ }^{b} \mathrm{~F}$ - foward. ${ }^{\mathrm{c}} \mathrm{R}$ - reverse. The primers Rep-YFV-GFP-F and Rep-YFV-GFP-R were used to construct the replicon repYFV-17D-GFP, while the primers RepYFV-Luc-F and Rep-YFV-Luc-R were used to construct repYFV-17D-Luc.

the reporter gene. Positive clones were grown in liquid trp dropout medium, and plasmid DNA extraction was performed using QIAprep Miniprep Kit according to manufacturer's instruction.

The second replicon (repYFV-17D-Luc) was also constructed using homologous recombination of one PCR product. The DNA template used in PCR reactions was the plasmid LNBr-WT that contains the Luc gene. The primers sequence is showed in Table I.

\section{E. COLI ELECTROPORATION}

In orde to amplify the DNA after homologous recombination, the purified yeast DNA was used to transform competent E. coli strain DH10B. Plasmid DNA were electroporated using $2 \mathrm{~mm}$ cuvettes on an ECM BTX electro cell manipulator $830^{\mathrm{TM}}$ (BTX, Holliston, MA) with the following settings: $2.75 \mathrm{kV}, 99 \mu \mathrm{sec}$ and 5 pulses with $1 \mathrm{sec}$ interval. Individual colonies were grown at $37^{\circ} \mathrm{C}$ overnight in LuriaBertani broth medium containing chloranfenicol as resistance marker. Plasmid DNA was then purified using the QIAGEN Plasmid Mid kit according manufacturer's instructions.

\section{IN VITRO TRANSCRIPTION}

DNA templates for in vitro transcription were produced by PCR amplification of the region containing the $\mathrm{T} 7$ promoter and the entire replicon of the relevant plasmids using Klentaq polymerase (Clontech). Full length PCR product were purified by phenol-chloroform, ethanol precipitated and then in vitro transcribed using MegaScript T7 kit (Ambion) supplemented with a $7 \mathrm{mG}(\mathrm{ppp}) \mathrm{G}$ cap analogue (Ambiom). The yield and integrity of transcripts were analyzed by gel electrophoresis under denaturing conditions. Aliquots of transcription reactions were used for electroporation of BHK-21 cells without any additional purification.

\section{RNA TRANSFECTION}

Approximately $2 \times 10^{6}$ BHK21 cells in $100 \mathrm{uL}$ Cytomix solution (Ansari et al. 2004) were 
electroporated with $5 \mu \mathrm{g}$ of in vitro transcribed RNA in 2 mm cuvettes using an ECM BTX electro cell manipulator $830^{\mathrm{TM}}$ (BTX, Holliston, MA) with five pulses at the setting of $600 \mathrm{~V}, 99 \mu \mathrm{sec}$ and $1 \mathrm{sec}$ of interval. After being at room temperature for $5 \mathrm{~min}$, the cells were ressuspendend in fresh medium. For immunofluorescence assays, transfected cells were spotted onto 24-well plate coated with 10-mm glass coverslips.

\section{IMMUNOFLUORESCENCE ASSAYS}

Indirect immunofluorescence assay were used to detect viral protein expression in replicontransfected cells. For this purpose, transfected cells on coverslips were rinsed with PBS and fixed with cold acetone at $-20^{\circ} \mathrm{C}$ for $5 \mathrm{~min}$. Then, cells were incubated at $37^{\circ} \mathrm{C}$ for 1 hour with a $1: 100$ dilution of a hyperimmune ascitic fluid raised against group B flaviviruses (Instituto Evandro Chagas), rinsed with PBS, followed by incubation with 1:100 dilution of a fluorescein isothiocyanate (FITC)-conjugated goat anti-mouse IgG antibody (Sigma-Aldrich) at $37^{\circ} \mathrm{C}$ for 1 hour. Following final washing, drying, and mounting, cells were visualized with a DMI 4000B fluorescence microscope (Leica).

\section{LIVE FLUORESCENCE ANALYSIS}

To observe GFP expression into live cells, repYFV17D-GFP-transfected cells were rinsed with 1XPBS buffer and visualized by fluorescence microscopy using a SP2 AOBS inverted fluorescence microscope (Leica). Green lantern plasmid DNA transfected cells were used as positive control.

\section{LUCIFERASE ACTIVITY ASSAY}

To measure luciferase activity, naive and repYFV17D-LUC-transfected BHK-21 cells were counted, washed with PBS and lysed by the addition of cell culture lysis buffer (Promega) according manufacturer's instructions. Cell lysate were then centrifuged, and $20 \mathrm{uL}$ of the resulting supernatant were mixed with $100 \mathrm{uL}$ of luciferase substrate prior measurement of luciferase activity using a Mithras LB 940 Bioanalyzer (Berthold).

\section{RESULTS}

\section{CONSTRUCTION OF YFV REPLICONS}

The subgenomic replicons derived from a full-length cDNA clone of 17D strain of YFV expressing biologically functional reporter genes (GFP and LUC) were constructed using a yeastbased homologous recombination cloning method.

The replicon repYFV-17D constructed from the plasmid pBSC-repYFV-17D has an in-frame deletion of almost entire structural protein coding sequence, but retained the first $63 \mathrm{nts} \mathrm{N}$-term of the capsid protein coding sequence and the $72 \mathrm{nts} \mathrm{C}$-term of the E-protein. These important sequences for flavivirus replication includes the sequence of cyclization replication and signal sequence for NS1 protein during flavivirus protein synthesis, respectively (Khromykh and Westaway 1997, Lindenbach et al. 2007). To allow the expression of reporter genes from flavivirus replicons, we used a strategy that involved the in-frame fusion of the reporter genes GFP and LUC, following the 21 codons encoding the N-terminus of the capsid protein.

The use of the yeast-based homologous recombination cloning technique allowed the construction of repYFV-17D-GFP and repYFV17D-Luc replicons in one step. Digestion of pBSCrepYFV-17D with NarI restriction enzyme and dephosphorylation of the ends yielded a linear plasmid unable to replicate in yeast, unless the plasmid was again circularized. Circularization was facilitated by recombination with overlapping DNA fragments, generating chimeric repYFV-17D sequences. After recombination in Saccharomyces cerevisae four clones of each replicon construct were selected for confirmation of recombination by PCR (Figures 2A and 3A), using specific primers that amplified the inserted region, related to each 
reporter gene in the YFV replicons. All the four selected clones for repYFV-17D-GFP and repYFV17D-Luc presented band size of 1,272 bp and 1.6 $\mathrm{Kb}$, respectively, as expected for the amplification of a fragment that comprises the reporter gene (GFP or Luc) and the N-terminal sequence of NS1 protein in the YFV-replicon. The yeast-based recombination method used in this work showed to be efficient for the construction of the YFV subgenomic replicons.
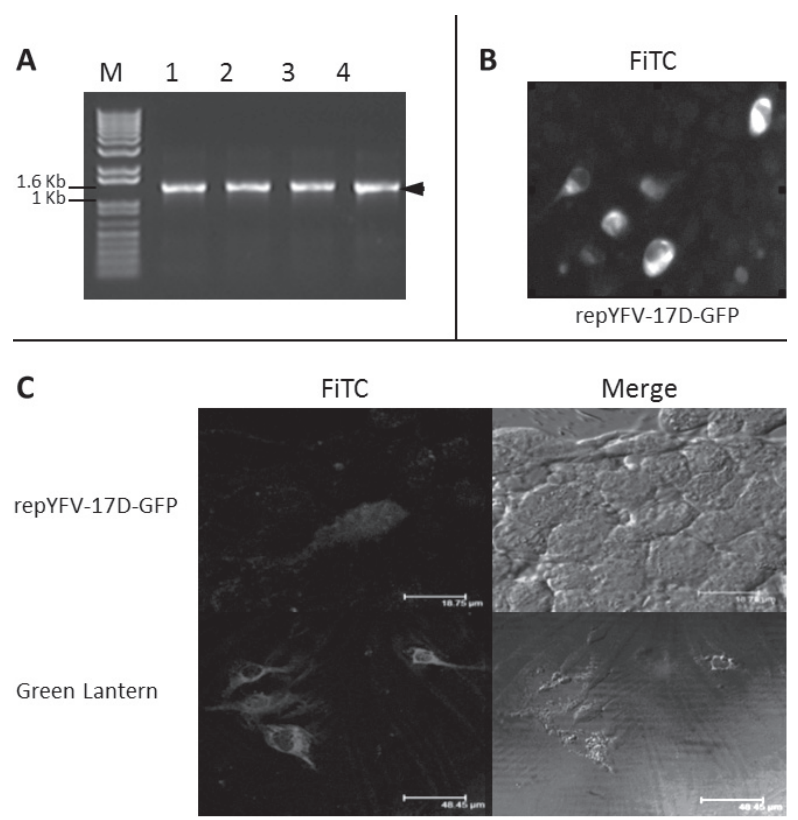

Figure 2 - Characterization of the subgenomic replicon repYFV-17DGFP. (A) Confirmation of the cloning of four clones repYFV-17D-GFP by homologous recombination in yeast. Agarose gel electrophoresis of the expected PCR product of 1,272 bp. The numbers correspond to clone tested (1-4). (B) Detection of protein expression of yellow fever virus by indirect immunofluorescence 48 hours after electroporation of BHK21 cells with RNA in vitro transcribed of repYFV-17D-GFP. (C) Detection of GFP expression by confocal microscopy in cells BHK21 electroporated with the replicon repYFV-17D-GFP (upper) and with Green Lantern DNA (botton) 48 hours post- electroporation. 630X oil immersion.

\section{CHARACTERIZATION OF YFV REPLICONS}

The green fluorescent reporter protein expression was detectable by fluorescence analysis of live GFP in BHK-21 cells as early as 48 hour after transfection with repYFV-17D-GFP replicon RNA as with the
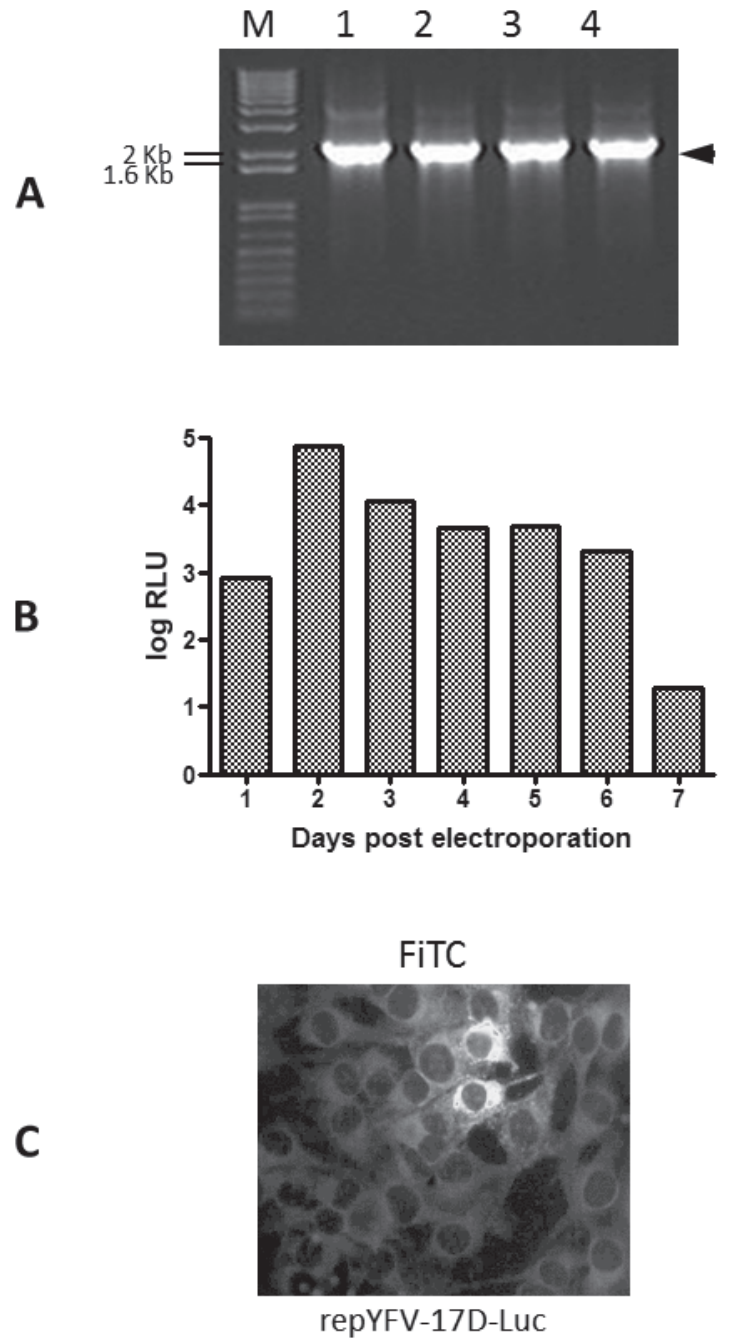

Figure 3 - Characterization of the subgenomic replicon repYFV-17DLuc. (A) Confirmation of the cloning of four clones repYFV-17D-Luc by homologous recombination in yeast. Agarose gel electrophoresis of the expected PCR product of $2.3 \mathrm{~Kb}$. The numbers correspond to clone tested (1-4). (B) Firelly luciferase activity detected in cell extracts from BHK21 cells electroprated with the replicon rep-YFV-17D-Luc during seven days post-electroporation. (C) Detection of protein expression of yellow fever virus by indirect immunofluorescence of BHK21 cells at 48 hours post-electropation with replicon RNA repYFV-17D-Luc in vitro transcribed. $400 \mathrm{X}$.

green lantern plasmid DNA (Figure 2C). Also, the replication of the replicon was indirectly confirmed by the accumulation of yellow fever virus specific proteins, detected by immunofluorescence staining of transfected cells using specific antibodies against flavivirus proteins. 
Luciferase activity was detected in cellular extracts prepared from BHK-21 cells electroporeted with in vitro transcribed repYFV-17D-Luc RNA for seven days post-electroporation. As shown in Figure 3B, the level of luciferase activity reached a maximum value at 48 hours post-electroporation. After this point time, the luciferase activity was also detected, but in a lower level until the minimum value had been reached at day seven. The autonomous replication of YFV replicon expressing the luciferase reporter gene (repYFV-17D-Luc) was also demonstrated by immunofluorescence analysis with specific antibodies to flavivirus proteins, 48 hours after transfection of BHK-21 cells (Figure $3 C)$. The results showed that the expression of the reporter gene was dependent on the amplification of the YFV replicon by RNA replication and that its expression may be the transient.

The efficient expression of the reporter genes GFP and Luc reveals the correct insertion of the gene cassette into the replicon, the correct translation/processing of the protein and the efficient replication of the YFV-replicon.

\section{DISCUSSION}

In yeast, homologous recombination is an important strategy to repair double-stranded DNA breaks and creat genetic diversity (Orr-Weaver et al. 1981, Kuzminov 2001). Overlapping DNA fragments undergo recombination readily when cotransformed into yeast cells (Oldenburg et al. 1997, Gibson et al. 2008, Panicali and Paoletti 1982, Post and Roizman 1981). So, the homologous recombination method can be effectively used to clone a desired gene into a plasmid and to generate chimeric genes with precise fusion junctions without the need of appropriate restriction sites.

A DNA fragment whose ends are identical to plasmid sequences can be directly inserted into a linearized vector by in vivo homologous recombination in yeast, alleviating the need for ligation in vitro. This method relies on sufficient homology at the ends of the DNA fragment and plasmid to engage the recombination machinery. At first, it were thought that 100 nts of homologous was required in order to recombinantion take place. Nowadays, it is known that $15 \mathrm{nts}$ of homologous sequence is sufficient to mediate homologous integration (Manivasakam et al. 1995). The present study shows that homologous ends of 25 nts incorporated into primers get PCR products to efficient yeast-based homologous recombination. This cloning strategy has yet a limited application in the flavivirus genome manipulations (Puri et al. 2000, Polo et al. 1997, Pang et al. 2001) and their use are encouraged mainly by the stability of these genomes when manipulated in yeast instead of bacteria. Difficulties are encountered to construct flavivirus infectious clones because of the apparent genomic instability when using prokaryotic cells, as Escherichia coli (Kapoor et al. 1995, Lai and Monath 2003, Polo et al. 1997, Sumiyoshi et al. 1992). For this reason, the use of the yeast Saccharomyces cerevisae for cloning strategies has also proved to be efficient to by-pass the deleterious effects and instability in E. coli (Polo et al. 1997).

Replicons of the flavivirus express all the nonstructural proteins in order to mimic the expression during a viral infection and has proven to be a powerful tool to study the role of non-structural proteins and viral replication (Khromykh et al. 1998, Lindenbach and Rice 1997). Moreover, amplification of replicon RNA in the cytoplasm of cells makes them excellent vectors for the expression of heterologous genes at high levels, so transient and stable (Khromykh 2000). Featuring one or more structural proteins deleted, replicons are competent for autonomous replication, but unable to form infectious viral particles (Jones et al. 2005, Kofler et al. 2004, Widman et al. 2008).

Cloning of genes reporters have been widely used in the manipulation of viral genomes ( $\mathrm{Ng}$ et al. 2007, Fayzulin et al. 2006, Scholle et al. 2004, Rossi 
et al. 2005, 2007) and is a valuable tool for evaluation of vector competence. The expression of these YFVbased replicons that encode reporter genes was found to be dependent on the amplification of input replicon RNA via RNA replication.

Most of the construction strategies of flavivirus reporter replicons previously proposed aim at the inclusion of the 3'-UTR reporter gene downstream of the IRES element of encephalomyocarditis virus (IRES-ECMV) to direct cap-independent translation of the reporter gene (Fayzulin et al. 2006, Khromykh and Westaway 1997, Shi et al. 2002, Scholle et al. 2004, Rossi et al. 2005). Insertions at the N-terminal of the NS1 of flavivirus replicons are followed by $2 \mathrm{~A}$ protease sequence of the foot and mouth disease virus (2A-FMDV) to ensure proper processing of the heterologous protein (Shustov et al. 2007) or IRES-ECMV (Jones et al. 2005, $\mathrm{Ng}$ et al. 2007). All these strategies are based on standard cloning methods with the need for ligation in vitro, the use of restriction sites and a long time consuming. Such methods generally involve a number of steps, and the transfer of viral genetic material to different plasmids for growth in various bacteria, for the different stages of the overall process. In addition, the location and number of particular restriction sites is often a limitation to the generation of specific site-directed mutants.

In this work we have demonstrated that yellow fever virus replicon vectors constructed by homologous recombination in yeast can be used for expression of foreign genes in mammalian cells. The GFP and Luc expression by replicons repYFV17D and repYFV-17D-GFP-Luc (Figures 2C and 3C), respectively, fall within the competence and replicative vector of these replicons. The efficiency of homologous recombination achieved was satisfactory (Figures 2A and 3A) and reinforces the applicability of this technique in studies of gene cloning.

YFV replicons lacking 2A protein sequence between the reporter gene and the NS1 signal sequence were previously found to be deficient in reporter gene expression (Jones et al. 2005). In contrast, we have constructed by homologous recombination in yeast functional replicons with insertion of a heterologous gene in this region. The expression of non-structural proteins in cells electroporated with RNA transcribed in vitro from both replicons, repYFV-17D-GFP (Figure 2B) and repYFV-17D-Luc (Figure 3B) revealed the replicative efficiency of these replicons. These results show that it is possible to insert heterologous genes between $\mathrm{C}$-terminal end of the cyclization sequence of $\mathrm{C}$ protein and $\mathrm{N}$-terminal end of the signal sequence of the envelope protein of the flavivirus replicons without interfering with viability.

As vaccine vectors or expression vectors for heterologous genes, replicons of the flavivirus present several advantages over conventional vectors, including: high levels of gene expression; capacity of autonomous replication; replication exclusively cytoplasmic, eliminating any possibility of chromosomal integration; inability to perform more than one cycle of infection, making them a safe tool for vaccine development, and small genome that allows easy manipulation (Anraku et al. 2002). Another advantage of the replicons are the different ways in which they can be used as immunizing: DNA, RNA or defective particles (Varnavski et al. 2000, Aberle et al. 2005, Ishikawa et al. 2008, Suzuki et al. 2009, Widman et al. 2008).

We present here an approach to the generation of replicons that reduces limitations of standard techniques for cloning and the number of steps needed to modify the viral genomes. The successful recovery of functional subgenomic replicons derived from RNA transcribed from an infectious clone YFV17D has implications in developing new vaccine strategies and tools for studies of viral replication and pathogenesis. Moreover, the genomic stability conferred by recombination system in yeast makes this tool even more reliable and safe for the use of replicons for different purposes. 


\section{RESUMO}

O replicon de RNA derivado do genoma de Flavivirus é uma ferramenta valiosa para o estudo de replicação viral independente da montagem e da maturação do virion, além de possuir um grande potencial para expressão de genes heterólogos. Neste estudo nós descrevemos a construção de replicons subgenômicos do vírus da febre amarela utilizando a técnica de recombinação homóloga em levedura. O plasmídeo contendo o replicon do vírus febre amarela cepa 17D (pBSC-repYFV-17D), caracterizado anteriormente, foi manipulado para a expressão heteróloga dos genes repórteres green fluorescent protein (repYFV-17D-GFP) e firelly luciferase (repYFV17D-Luc). Ambos os replicons foram construídos por recombinação homóloga entre o vetor pBSC-repYFV17D linearizado e o produto de PCR contendo 25 nucleotídeos terminais homólogos incorporados aos oligonucleotídeos iniciadores. A organização genômica dos construídos é semelhante ao repYFV-17D, com inserção de um gene repórter entre os restantes 63 nucleotídeos N-terminais da proteína do capsídeo e 72 nucleotídeos C-terminais da proteína E. Os replicons repYFV-17D-GFP e repYFV-17D-Luc mostraram uma eficiente replicação e expressão dos genes repórteres. A técnica de recombinação homóloga em levedura usada neste estudo demonstrou ser aplicável à manipulação do genoma do vírus da febre amarela para a construção de replicons subgenômicos.

Palavras-chave: técnica de clonagem, recombinação homóloga, replicon, gene repórter, vírus da febre amarela.

\section{REFERENCES}

ABerle JH, Aberle SW AND Kofler RMANDMANDL CW. 2005. Humoral and cellular immune response to RNA immunization with flavivirus replicons derived from tickborne encephalitis virus. J Virol 79: 15107-15113.

ANRAKU I, HARVEY TJ, LinEdALE R, GARDNER J, HARRICH D, SuHrbIER A AND KHROMYKH AA. 2002. Kunjin virus replicon vaccine vectors induce protective CD8+ T-cell immunity. J Virol 76: 3791-3799.

ANSARI IH, CHEN LM, LIANG D, GIL LH, ZHONG W AND DONIS RO. 2004. Involvement of a bovine viral diarrhea virus NS5b locus in virion assembly. J Virol 78: 9612-9623.
Bredenbeek PJ, Kool EA, Lindenbach B, Huijkman N, RICE CM AND SPAAN WJ. 2003. A stable full-length yellow fever virus cDNA clone and the role of conserved rna elements in flavivirus replication. J Gen Virol 84: 1261-1268.

Fayzulin R, Scholle F, Petrakova O, Frolov I And MASON PW. 2006. Evaluation of replicative capacity and genetic stability of west nile virus replicons using highly efficient packaging cell lines. Virology 351: 196-209.

GeHrke R, ECKER M, ABERLE SW, AlLison SL, Heinz FX AND MANDL CW. 2003. Incorporation of tick-borne encephalitis virus replicons into virus-like particles by a packaging cell line. J Virol 77: 8924-8933.

GIBSON DG. 2009. Synthesis of DNA fragments in yeast by one-step assembly of overlapping oligonucleotides. Nucleic Acids Res 37: 6984-6990.

GIBSON DG ET AL. 2008. One-step assembly in yeast of 25 overlapping DNA fragment to form a complete synthetic Mycoplasma genitalium genome. PNAS 105(51): 2040420409.

GuBler DJ, KunO G AND MARHOFF L. 2007. Flaviviruses, In: Knife DM et al. (Eds), Fields' Virology, Philadelphia: Quebecor Versailles, Philadelphia, USA, p. 1153-1252.

IMOTO JI AND KONISH E. 2007. Dengue tetravalent DNA vaccine increases its immunogenicity in mice when mixed with a dengue type 2 subunit vaccine or an inctivacted japonese encephalitis vaccine. Vaccine 25: 1076-1084.

ISHIKAWA T, WIDMAN DG, BOURNE N, KONISHI E AND MASON PW. 2008. Construction and evaluation of a chimeric pseudoinfectious virus vaccine to prevent japanese encephalitis. Vaccine 26: 2772-2781.

JONES CT, PATKAR CG AND KUHN RJ. 2005. Construction and applications of yellow fever virus replicons. Virology 331: 247-259.

KAPOOR M, ZHANG L, MOHAN PM AND PADMANABHAN R. 1995. Synthesis and characterization of an infectious dengue virus type-2 RNA genome (New Guinea C strain). Gene 162: 175-180.

KHROMYKH AA. 2000. Replicon-based vectors of positive strand RNA viruses. Curr Opin Mol Ther 2: 555-569.

KHROMYKH AA, KenNey MT AND WeStAWAY EG. 1998. Trans-complementation of flavivirus rna polymerase gene NS5 by using kunjin virus replicon-expressing BHK cells. J Virol 72: 7270-7279.

Khromykh AA AND WestaWAy EG. 1994. Completion of kunjin virus RNA sequence and recovery of an infectious RNA transcribed from stably cloned full-length cDNA. J Virol 68: 4580-4588.

KHROMYKH AA AND WeStaWAY EG. 1997. Subgenomic replicons of the flavivirus kunjin: Construction and applications. J Virol 71: 1497-1505.

Kofler RM, Aberle JH, Aberle SW, Allison SL, Heinz FX AND MANDL CW. 2004. Mimicking live flavivirus immunization with a noninfectious rna vaccine. Proc Natl Acad Sci USA 101: 1951-1956.

KÜMMERER BM. 2006. The molecular biology of yellow fever virus, In: Kalitzky M and Borowski P (Eds), Molecular biology of the flavivirus, Norfolk, Cromwell Press, Norfolk UK, p. 1-16. 
KUZMINOV A. 2001. DNA replication meets genetic exchange: Chromosomal damage and its repair by homologous recombination. Proc Natl Acad Sci USA 98: 8461-8468.

LAI CJ AND Monath TP. 2003. Chimeric flaviviruses: Novel vaccines against dengue fever, tick-borne encephalitis, and japanese encephalitis. Adv Virus Res 61: 469-509.

LINDENBACH BD AND RiCE CM. 1997. Trans-complementation of yellow fever virus ns1 reveals a role in early RNA replication. J Virol 71: 9608-9617.

LINDENBACH BD, THIEL HJ AND RICE CM. 2007. Flaviviridae: The viruses and their replication, In: KNIPE DM et al. (Eds), Fields' virology, Philadelphia, Quebecor Versailles, Philadelphia USA p. 1100-1152.

MANivasaKam P, Weber SC, MCELVER J AND SCHIESTL RH. 1995. Micro-homology mediated PCR targeting in Saccharomyces cerevisiae. Nucleic Acids Res 23: 27992800.

Mosimann AL, DE Borba L, Bordignon J, MASON PW AND DOS SANTOS CN. 2010. Construction and characterization of a stable subgenomic replicon system of a brazilian dengue virus type 3 strain (BR DEN3 29002). J Virol Methods 163: 147-152.

NG CY, Gu F, PHONG WY, Chen YL, LIM SP, DAVIDSON A AND VASUdEVAN SG. 2007. Construction and characterization of a stable subgenomic dengue virus type 2 replicon system for antiviral compound and siRNA testing. Antiviral Res 76: 222-231.

Oldenburg KR, Vo KT, Michaelis S ANd PAdDOn C. 1997. Recombination-mediated PCR-directed plasmid construction in vivo in yeast. Nucleic Acids Res 25: 451-452.

ORR-WEAVER TL, SZOSTAK JW AND ROTHSTEIN RJ. 1981. Yeast transformation: A model system for the study or recombination. Proc Natl Acad Sci USA 78: 6354-6358.

Pang X, Zhang M And Dayton AI. 2001. Development of dengue virus type 2 replicons capable of prolonged expression in host cells. BMC Microbiology 1: 28.

PANICALI D AND PAOLETTI E. 1982. Construction of poxviruses as cloning vectors: Insertion of the thymidine kinase gene from herpes simplex virus into the DNA of infectious vaccinia virus. Proc Natl Acad Sci USA 79: 4927-4931.

Polo S, KetNer G, LEVIS R AND FALGOUT B. 1997. Infectious rna transcripts from full-length dengue virus type 2 cdna clones made in yest. J Virol 71: 5366-5374.

Post LE AND RoIZMAN B. 1981. A generalized technique for deletion of specific genes in large genomes: Alpha gene 22 of herpes simplex virus 1 is not essential for growth. Cell 25: 227-232.

Puri B, Polo S, Hayes CG and Falgout B. 2000. Construction of full lenght infectious clone for dengue-1 virus western pacific, 74 strain. Virus Genes 20: 57-63.
Rossi SL, FAYZuLIN R, DEWSBURy N, BOURNE N AND MASON PW. 2007. Mutations in west nile virus nonstructural proteins that facilite replicon persistence in vitro attenuate virus replication in vitro and in vivo. Virology 364: 184-195.

Rossi SL, ZHAO Q, O'DONNELL VK AND MASON PW. 2005 Adaptation of west nile virus replicon to cells in culture and use of replicon-bearing cells to probe antiviral action. Virology 331: 457-470.

SAMBROOK J AND RUSSELL DW. 2001. Molecular cloning: A laboratory manual. $3^{\text {rd }}$ ed., New York: Cold Spring Harbor Laboratory Press.

Scholle F, Girard YA, ZhaO Q, Higgs S AND Mason PW. 2004. Trans-packaged west nile virus-like particles: Infectious properties in vitro and in infected mosquito vectors. J Virol 78: 11605-11614.

SHANKS RM, KadOURI DE, MACEACHRAN DP AND O'TOOLE GA. 2009. New yeast recombineering tools for bacteria. Plasmid 62: 88-97.

ShI PY, TILGNER M AND Lo MK. 2002. Construction and characterization of subgenomic replicons of New York strain of west nile virus. Virology 296: 219-223.

Shustov AV AND MASON PWANDFROLOV I. 2007. Production of pseudoinfectious yellow fever virus with a twocomponent genome. J Virol 81: 11737-11748.

SUMIYOSHI H AND HoKE CHANDTRENT DW. 1992. Infectious japanese encephalitis virus rna can be synthesized from in vitro-ligated cDNA templates. J Virol 66: 5425-5431.

SUZUKI R, WINKELMANN ER AND MASON PW. 2009. Construction and characterization of a single-cycle chimeric flavivirus vaccine candidate that protects mice against lethal challenge with dengue virus type 2. J Virol 83: 1870-1880.

VARNAVSKI AN AND KHROMYKH AA. 1999. Noncytopathic flavivirus replicon rna-based system for expression and delivery of heterologous genes. Virology 255: 366-375.

VARNAVSKI AN, YOUNG PR AND KHROMYKH AA. 2000. Stable high-level expression of heterologous genes in vitro and in vivo by noncytopathic DNA-based kunjin virus replicon vectors. J Virol 74: 4394-4403.

WIDMAN DG, ISHIKAWA T, FAYZULIN R, BOURNE N AND MASON PW. 2008. Construction and characterization of a second-generation pseudoinfectious west nile virus vaccine propagated using a new cultivation system. Vaccine 26: 2762-2771.

YAMSHCHIKOV G, BORISEVICH V, KWOK CW, NiSTLER R, Kohlmeier J, Seregin A, Chaporgina E, Benedict S AND YAMSHCHIKOV V. 2005. The suitability of yellow fever and japanese encephalitis vaccines for immunization against west nile virus. Vaccine 23: 4785-4792. 